\title{
METHODOLOGY FOR OPTIMIZATION OF COEFFICIENT FOR ORE RECOVERY IN SUBLEVEL CAVING MINING METHOD
}

\section{METODOLOGIJA OPTIMIZACIJE KOEFICIJENTA ISKORIŠĆENJA RUDE KOD PODETAŽNE METODE SA ZARUŠAVANJEM}

Mijalkovski Stojance', Despodov Zoran', Mirakovski Dejan', Adjiski Vancho $^{1}$, Doneva Nikolinka ${ }^{1}$

Received: April 7, 2017

Accepted: May 29, 2017

\begin{abstract}
Ore recovery and ore dilution have an important role for efficient operation of a mine. With each increase in percentage of ore dilution and reduced ore recovery there is negative impact on the economic value of the ore reserves. These parameters are mainly controlled with quality mining project and in situ analysis. The primary goal of this science paper is to present the methodology for optimization of coefficient for ore recovery and ore dilution in sublevel caving mining method. The optimization will be carried out through economic parameters, ie by calculating the net present value (NPV).
\end{abstract}

Keywords: recovery, dilution, sublevel caving, net present value (NPV)

Apstrakt: Iskorisćenje i osiromašenje rude imaju važnu ulogu za rentabilno poslovanje nekog rudnika. Svaki procenat povećanja osiromašanje i smanjenja iskorišćenja rovne rude negativno utiće na ekomomičnosti poslovanja rudnika. Ove parametre mogu se kontrolisati sa neposrednim praćenjem sadržaja korisnih komponenata u rudi i zapremine otkopane rudne rezerve.

$\mathrm{U}$ ovom radu biće prezentovana metodologija optimizacije koeficijenta iskorisćenja i osiromašenja rude kod metode sa podetažnim zarušavanjem rude i okolne stene. Optimizacija biće izvršena preko ekonomskih parametara, odnosno proračunom neto sadašnje vrednosti (NPV).

Ključne reči: iskorišćenje, osiromašenje, podetažna otkopna metoda, neto sadašnja vrednost

\section{INTRODUCTION}

Taking into account that geological reserves of useful minerals in the world day by day are gradually decreasing due to growing demand for metal, non-metal and energy mineral resources, which is a result of increasing economic growth of countries like: China, India, Russia, Brazil, etc. Also taking into account the fact that minerals are non-

${ }^{1}$ Faculty of Natural and Technical Sciences, University Goce Delčev - Štip emails: stojance.mijalkovski@ugd.edu.mk; zoran.despodov@ugd.edu.mk; dejan.mirakovski@ugd.edu.mk adziski.v@gmail.com; nikolinka.doneva@ugd.edu.mk; 
renewable materials, this arises the need for rational use of geological ore reserves in their exploitation and this is a problem that never loses its importance and will always will be subject to more detailed research (Jakšić and Nedeljković, 2008).

Underground mining exploitation of mineral resources in the near and distant future will be done in degraded conditions for exploitation of mineral deposits due to declining content of the ore, moving the exploitation to greater depths and also the increasing investment and production costs. In order for economical exploitation in these conditions it is necessary to solve a number of technical - technological problems. One of the problems that have primary importance is the technology of ore exploitation and ore processing (Milicevic 2008; Milicevic and Milic 2013).

The determination of coefficient for ore recovery of mineral reserves in underground mining, except with mining-geological factors (Mijalkovski 2013; Mijalkovski et al. 2015), it is necessary also to be determined based on other factors such as technological and economic factors (Gocevski and Mijalkovski 2009; Ivanovski 1986; Mijalkovski 2015).

The calculated coefficient of ore recovery of mineral reserves in a deposit is usually called an optimum level of ore recovery exploitation.

\section{METHODOLOGY FOR OPTIMIZATION OF COEFFICIENT FOR ORE RECOVERY IN SUBLEVEL CAVING MINING METHOD}

To systematize the procedures of the proposed methodology to optimize ore recovery/losses and ore dilution, ie to perform optimization of the coefficient of ore recovery of mineral reserves in underground mining for metal ore deposits using sublevel caving mining method, it is made basic model (block diagram) for the methodology, which is shown in Figure 1.

Because this science paper considers the method of ore exploitation with sublevel caving mining, in which the coefficients of recovery/losses and ore dilution are in mutual functional dependence, hereafter will be treated as a methodology for optimization of the ore recovery/losses and ore dilution.

As can be seen from Figure 1, the proposed methodology for optimization of the ore recovery/losses of geological reserves, consists of several steps.

The first step includes defining the geological parameters of the ore deposit (Gluščevič 1974; Ivanovski 1986; Mijalkovski 2015; Milicevic and Milic 2013), including the following:

Ore reserves (classification and categorization of mineral reserves);

Content of metals in geological reserves;

Limit contents of metals in geological reserves. 
The second step involves defining the technological parameters for the exploitation of the ore deposit (Ivanovski 1986; Mijalkovski 2015; Mijalkovski et al. 2015; Mijalkovski et al. 2015), including the following:

Determine the optimal annual production capacity of the mine;

Age of exploitation of the ore deposit;

Content of metals in ore;

- $\quad$ Recovery of ore in excavation;

- $\quad$ Dilution of ore during excavation;

- $\quad$ Flotation recovery of metals;

- $\quad$ Metallurgical recovery of metals.

The third step involves the calculation of economic parameters (Bluszcz and Kijewska 2016; Despodov 2008; Ivanovski 1986; Mijalkovski 2015; Mijalkovski et al. 2014), including the following:

- $\quad$ Costs (capital and operating costs);

- $\quad$ Income (price of metals in the stock market, value of the ore, total income);

- $\quad$ Calculation of the net present value (NPV).

- $\quad$ Calculation of the internal rate of return (IRR).

The fourth step of the methodology can be called a step of decision, where actually is carried out the maximization of net present value (NPV) while changing the values of the coefficient for ore recovery (Mijalkovski, 2015). Optimal values for the ore recovery are those who get the greatest value for the net present value (NPV). Net present value is calculated as the difference between total revenues and total costs of ore production. 


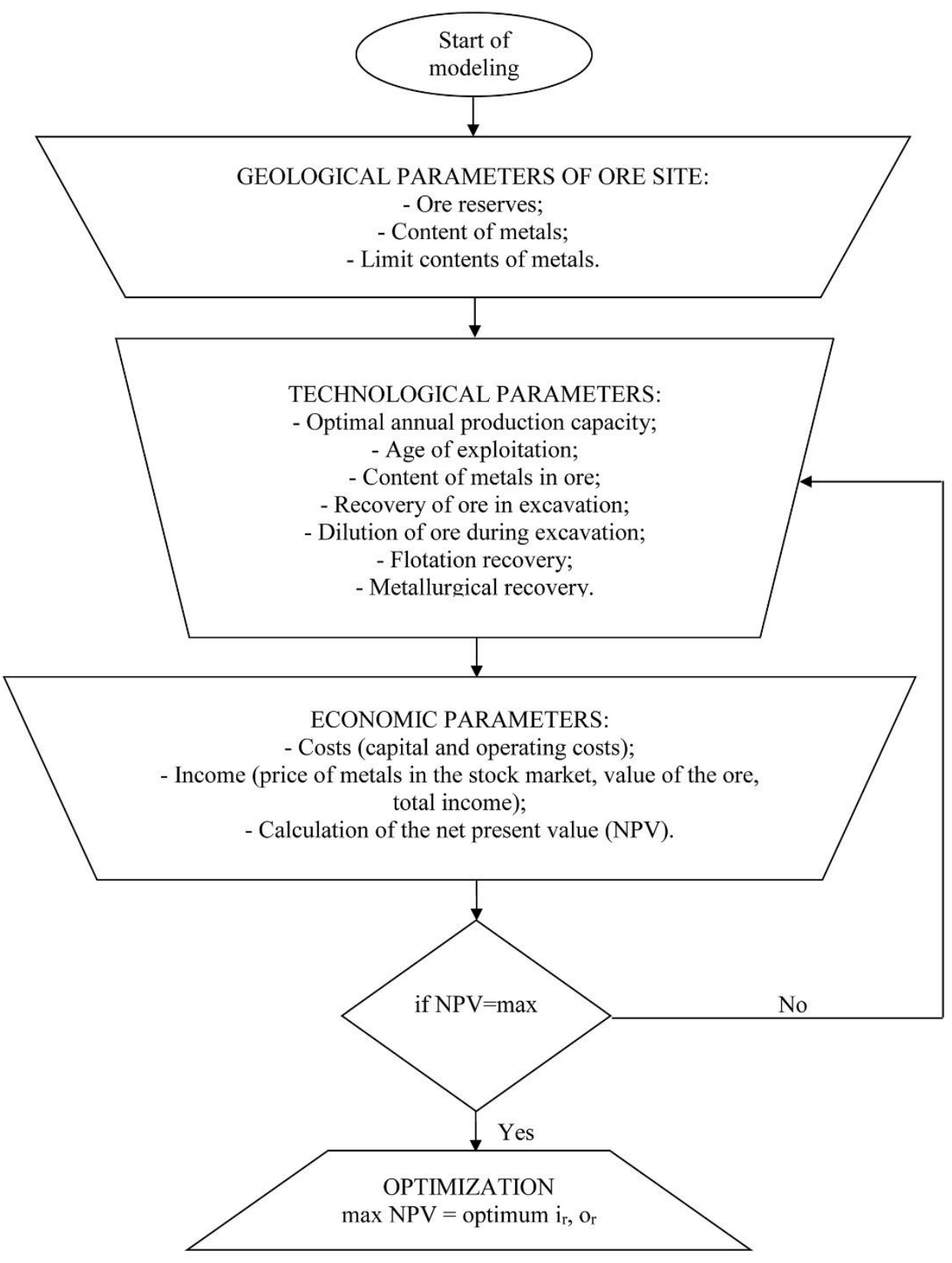

Figure 1 Basic concept of the proposed methodology for optimization of the ore recovery/losses and ore dilution 
Considering that it is very difficult mathematically and experimentally to determine the degree of ore recovery and ore dilution, it is necessary to perform their optimization through economic parameters, ie maximization of net present value (NPV). In determining the optimal ratio for ore recovery coefficient is reviewed several variants (Ivanovski 1986; Mijalkovski 2015). Zone or interval to optimize the ore recovery coefficient in sublevel caving mining method is usually in ranges from 70 to $90 \%$, while the ratio of the ore dilution ranges from 10 to $30 \%$. In order to calculate the coefficient of dilution, for a value of the coefficient of recovery, it is necessary first to determine the functional dependence between these two coefficients for a particular mine site. This functional dependence can be obtained by applying the method of least squares. Figure 2 , shows the functional dependence between the coefficient of ore recovery and ore dilution, with a display area of optimization (Ivanovski 1986; Mijalkovski 2015).

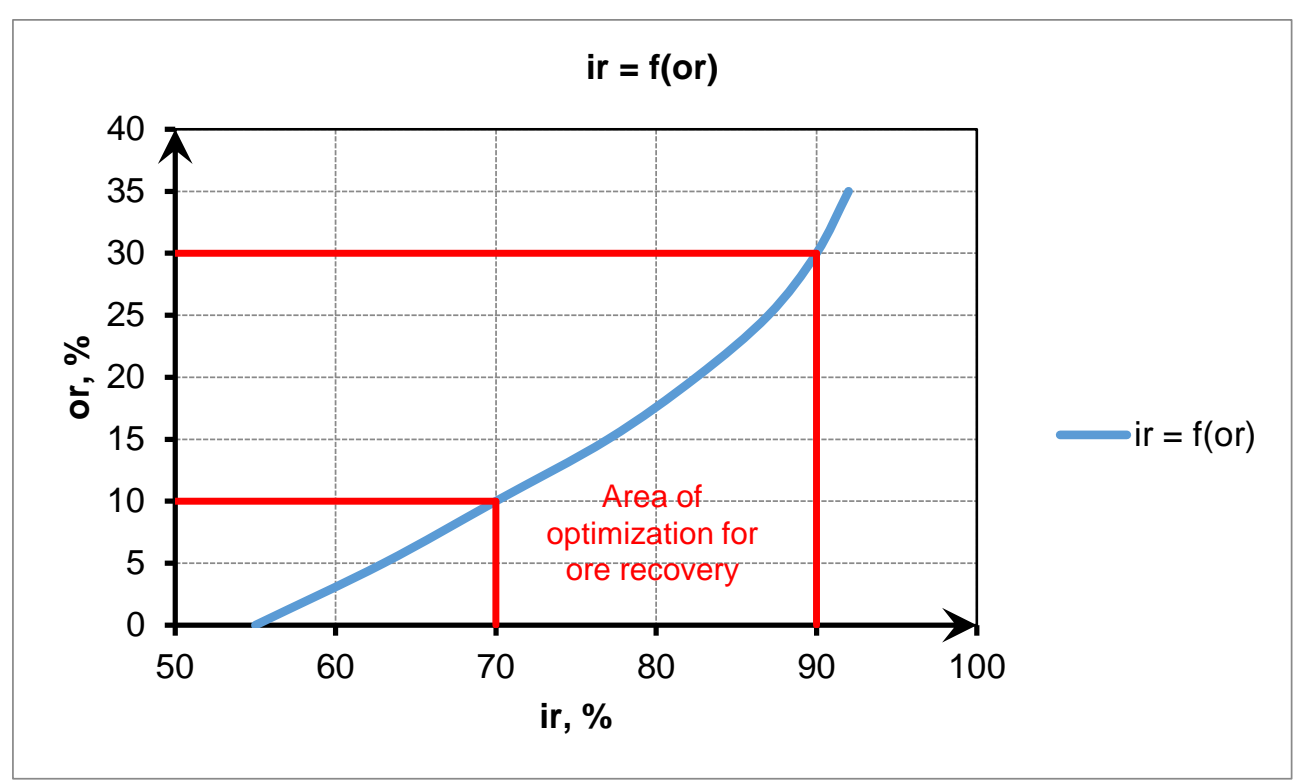

Figure 2 Functional dependence between the coefficient of ore recovery and ore dilution with a display area of optimization

The coefficient of ore recovery/loses has big influence of the life of mine exploitation, and also the total revenues. The coefficient of ore dilution which is in close functional dependency with ore recovery, most have an impact on the value of a ton of ore or the value of a ton of concentrate, and with thus the size of the total revenues. Also, the coefficient of ore dilution affects the size of the production costs and the value of flotation recovery of metals in the technological process (Mijalkovski, 2015).

For different values of the coefficient of ore recovery and ore dilution, we get different values for the total costs and revenue exploitation of an ore body. Having calculated the 
total costs and revenue, then we calculate the net present value (NPV) for each variant, ie for each value of the coefficient of ore recovery and ore dilution. For the one variant where you get the biggest value for the net present value (NPV), that variant is taken as optimal, and that determines the optimal ratio for the coefficient of ore recovery and ore dilution in the mine (Mijalkovski, 2015).

On Figure 3 is given a dependency of the net annual inflow with the exploitation time of a mine site, with different values of coefficient of ore recovery and ore dilution (Mijalkovski, 2015).

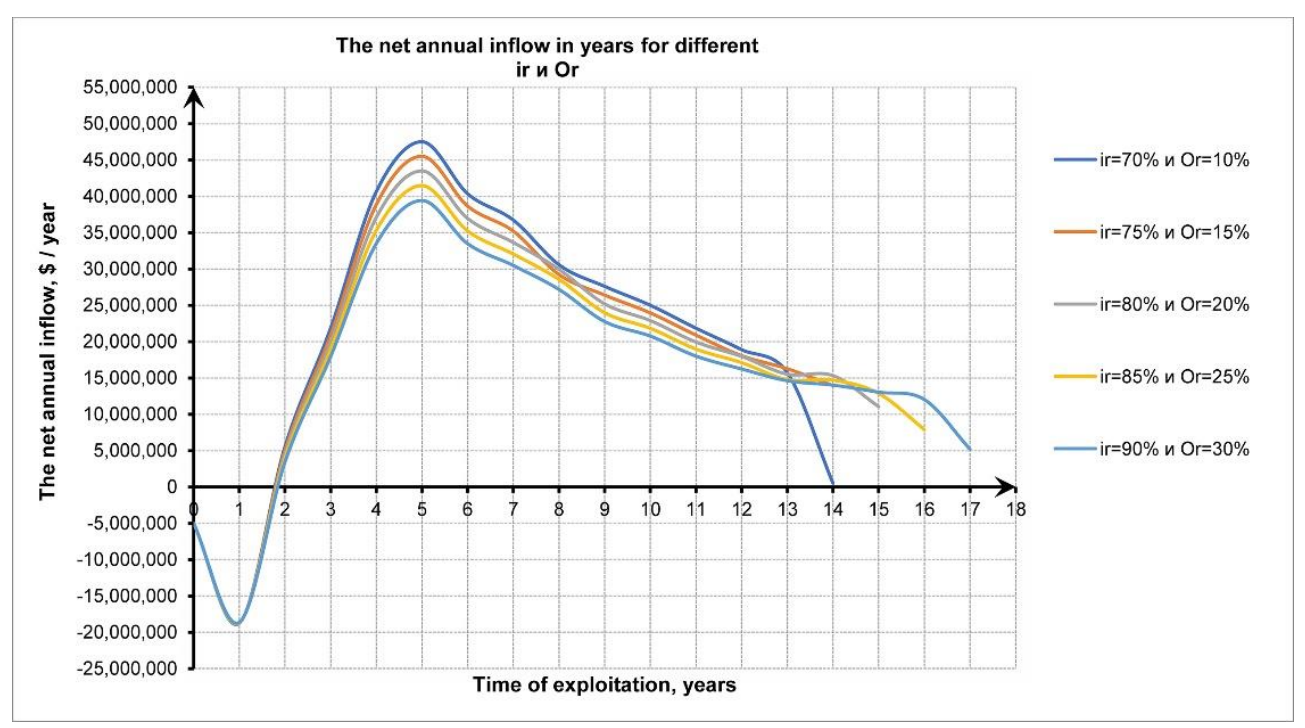

Figure 3 Comparison of net annual inflow in years for various values of the coefficient of ore recovery and ore dilution

On Figure 4 is given a functional dependence between the net present value and the coefficient of ore recovery from the mining excavation. 


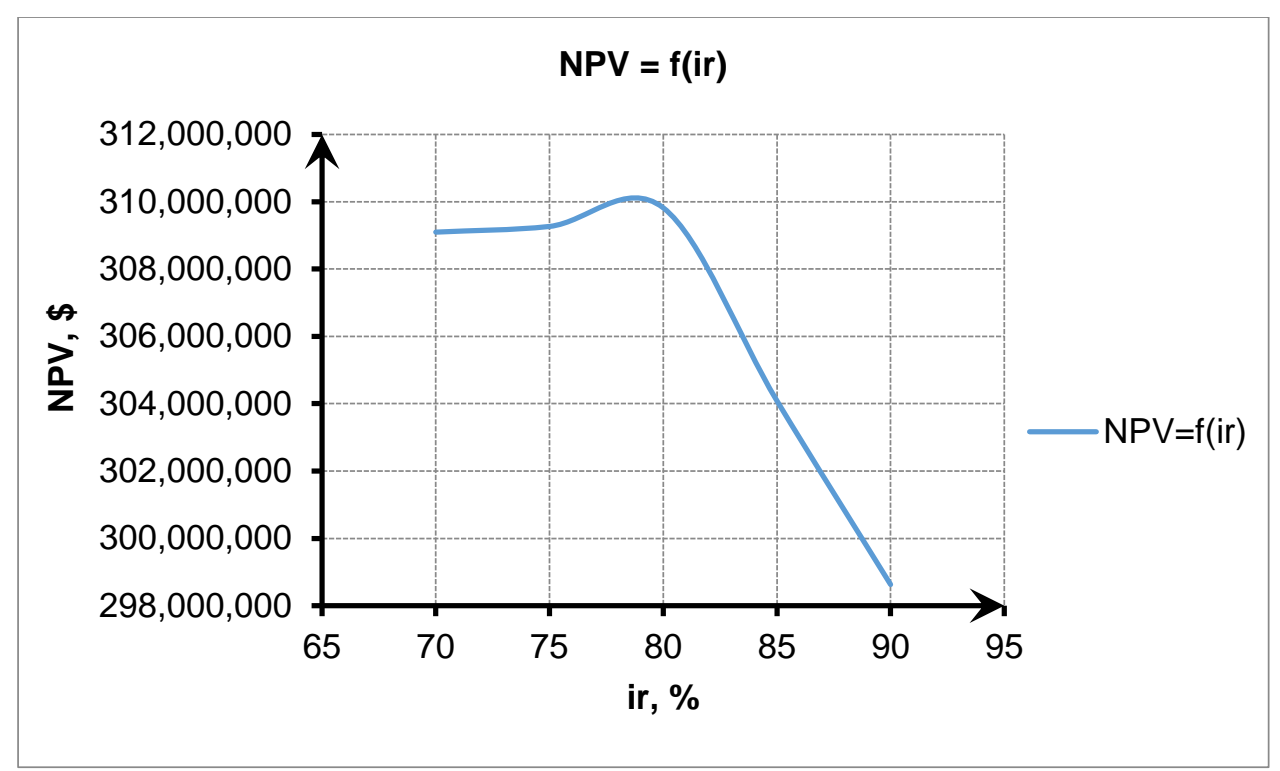

Figure 4 Functional dependence between the net present value (NPV) and ore recovery coefficient $\left(i_{r}\right)$

On Figure 5 is given a functional dependence between the net present value and the coefficient of ore dilution from the mining excavation.

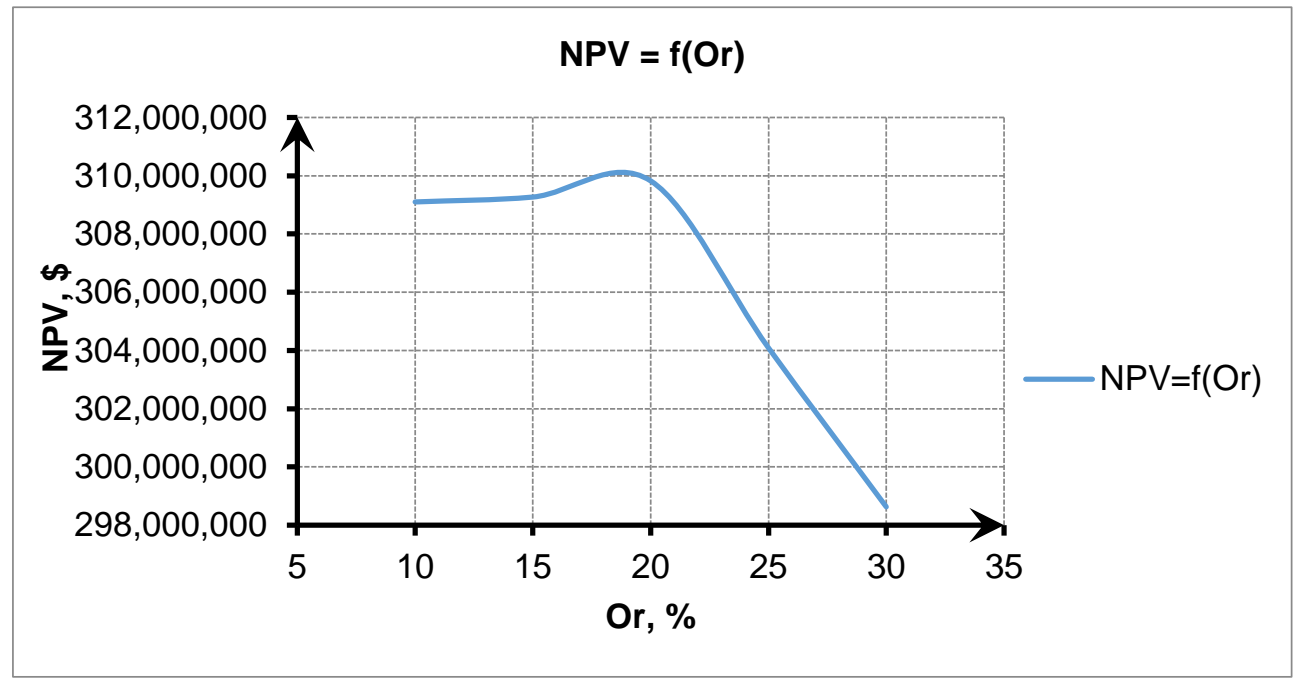

Figure 5 Functional dependence between the net present value (NPV) and ore dilution coefficient $\left(o_{r}\right)$ 
From Figure 4 we can conclude that the optimal value of the coefficient of ore recovery from the mining excavation is ir $=80 \%$, and from Figure 5 we can conclude that the optimal value of the coefficient of ore dilution from the mining excavation is $\mathrm{Or}=20 \%$. With this methodology are made the optimization factors for the coefficients of ore recovery and ore dilution.

\section{CONCLUSION}

Considering that the coefficient of ore recovery as technical and economic parameter of the mining excavation is very difficult to be accurately determine, because it depends on a number of factors, that's way in this science paper was developed methodology for determining the optimal value based on economic parameters, with previous adoption of the area-interval optimization. Based on experimental studies of similarity models is determined the functional relationship between the coefficients of ore recovery and ore dilution in the underground mine for lead and zinc "Sasa" - R. Macedonia, where the coefficient of ore recovery is in the range of 70 to $90 \%$, while the coefficient of ore dilution in the range of 10 to $30 \%$. The results of optimization showed that in the mining conditions of underground mine for lead and zinc "Sasa" - R. Macedonia the optimal values are:

- Coefficient ore recovery: ir $=80 \%$

- Coefficient ore dilution: $\mathrm{Or}=20 \%$.

\section{REFERENCES}

BLUSZCZ A. and KIJEWSKA A. (2016) Factors creating economic value added of mining company. Archives of mining sciences, 61(1), pp. 109-123.

GLUŠČEVIČ B. (1974) Otvaranje i metode podzemnog otkopavanja rudnih ležišta. Beograd: Univerzitet u Beogradu - Rudarsko-geološki fakultet.

GOCEVSKI V. and MIJALKOVSKI S. (2009) Избор на оптимални вредности за искористување и осиромашување на рудата при подетажниот метод со зарушување на кровината во ревир "Свиња река" во рудникот "Саса". Македонско рударство и геологија, 15 , рр. 20-25.

DESPODOV Z. (2008) Примена на методот за Нето-Сегашна Вредност (NPV) за оценување на исплатливоста на инвестициите во рударството. Македонско рударство и геологија, 8, pp. 22-24.

IVANOVSKI S. (1986) Придонес во одредувањето на параметрите за методата подетажно зарушување, со експериментални испитувања на модели од техничко економски аспект, за рудни тела со благ пад и поголема моќност, со посебен осврт на оловно иинковото лежиште "Свиња река". Unpublished thesis (PhD), Rudarsko-geološki fakultet, Štip. 
JAKŠIĆ M. and NEDELJKOVIĆ B. (2008) Uzroci gubitaka rudnih rezervi u metaličnim rudnicima. Podzemni radovi, 16, pp. 75-81.

MIJALKOVSKI S. (2013) Најважни показатели кои имаат влијание врз искористувањето (загубите) и осиромашувањето на рудата кај методата со подетажно зарушување. Македонско рударство и геологија, 23, pp. 30-33.

MIJALKOVSKI S. et al. (2014) Methodology for development of economic assessment for determining justification for exploitation of ore deposits. Natural resources and technology, 8(8), pp. 19-29.

MIJALKOVSKI S. et al. (2015) Determination and monitoring of ore recovery and dilution coefficients in SASA lead and zinc mine - M. Kamenica, R. Macedonia. Podzemni radovi, 26, pp. 1-9.

MIJALKOVSKI S. (2015) Optimizing of the recovery of ore reserves for underground mining of metal ore deposits. Unpublished thesis ( $\mathrm{PhD})$, Faculty of natural and technical sciences, Stip.

MIJALKOVSKI S. et al. (2015) Method for determining on the indicators for recovery and dilution of the ore. In: 8th expert conference themed: Technology of underground and surface mining of mineral raw materials. Krusevo, 13-15 November 2015. Kavadarci: Association of mining and geology engineers of Macedonia, pp. 118-125

MIJALKOVSKI S. et al. (2015) Recovery and ore dilution at the mining methods. Natural resources and technology, 9(9), pp. 19-28.

MILICEVIC Z. (2008) Metode podetažnog i blokovskog zarušavanja. Bor: Tehnički fakultet u Boru.

MILICEVIC Z. and MILIC V. (2013) Tehnologija podzemne eksploatacije ležišta mineralnih sirovina. Bor: Tehnički fakultet u Boru. 
